The University of Maine

\title{
DigitalCommons@UMaine
}

Marine Sciences Faculty Scholarship

School of Marine Sciences

11-1-1991

\section{Revision of the Cumacean Family Leuconidae}

Les Watling

University of Maine - Main, watling@maine.edu

Follow this and additional works at: https://digitalcommons.library.umaine.edu/sms_facpub

\section{Repository Citation}

Watling, Les, "Revision of the Cumacean Family Leuconidae" (1991). Marine Sciences Faculty Scholarship. 108.

https://digitalcommons.library.umaine.edu/sms_facpub/108

This Article is brought to you for free and open access by DigitalCommons@UMaine. It has been accepted for inclusion in Marine Sciences Faculty Scholarship by an authorized administrator of DigitalCommons@UMaine. For more information, please contact 


\title{
REVISION OF THE CUMACEAN FAMILY LEUCONIDAE
}

\author{
Les Watling
}

\begin{abstract}
A B S T R A C T
The family Leuconidae currently contains 99 species. With the exception of Epileucon, all genera in the family were established by 1907 . All new species have been subsequently assigned to those genera, gradually producing genera distinguishable on the basis of single characters. In this paper Epileucon is reduced to a subgenus of Leucon as proposed by Băcescu (1988), and the species of Leucon are further apportioned among the subgenera Leucon Krøyer, Macrauloleucon, new subgenus, Crymoleucon, new subgenus, and Alytoleucon, new subgenus. In addition, the new genera Ommatoleucon, Austroleucon, Nippoleucon, and Bytholeucon are proposed, and the genus Coricuma Watling and Breedy is added to this family. The new genus Americuma, with unclear family affiliations, is proposed for a species previously assigned to Heteroleucon. Complete diagnoses are provided for all genera and keys are given to all genera and species.
\end{abstract}

The Leuconidae is one of the oldest of all cumacean families, having been established by Sars in 1878 for the genera Leucon and Eudorella. Eudorellopsis was created by Sars in 1882 to accommodate two previously described species. Additional species from the North Atlantic and Mediterranean region gradually swelled the contents of these genera, due especially to the efforts of Sars (13 species). In the early 1900 's, as material from various expeditions became available, many more new species were described. However, only a few belonged to the new genera described by Zimmer (Pseudoleucon) in 1903 and Calman (Hemileucon, Heteroleucon, and Paraleucon) in 1907. These genera accommodated all subsequent new species until Jones (1956) proposed Epileucon. The family presently contains 99 species assigned (occasionally with doubt) to those eight genera.

Bishop (1981a) described a number of new species which he assigned to Epileucon. He noted that the original diagnosis of Epileucon was based on a character ("absence of a serrated dorsal crest on the carapace of the female," Jones, 1956) that did not show stability even in the type species. However, based on an extensive examination of deep Atlantic leuconids, the genus was rediagnosed using a suite of characters, chief among them being the presence on pereionite 5 of at least one pair of anteriorly curved ventral teeth (Bishop, 1981a). All other characters were acknowledged by Bishop to occur also in some or several species of Leucon. Băcescu (1988) rejected the genus Epi- leucon, suggesting that the characters proposed were not significant and did not define all species in the genus. Instead, he proposed that Leucon should be divided into the subgenera Leucon and Epileucon, recognizing that the species in this genus could be segregated into discrete groups. In the following account, several other subgenera are proposed, each of which are hypothesized to be a phylogenetic lineage within the genus.

With the exception of Epileucon, there have been no new genera created for the $60+$ species described since 1907 . For most of the shallow northern hemisphere species, this has not been a problem, since they fit quite comfortably into the genera established earlier for species from this region. For species from Asia and the South Pacific, Central America, and the deep sea, use of the established genera has been problematic. In several cases the generic diagnoses have been so stretched that only one or two characters continue to hold a genus together. Occasionally, the few members of a genus do not look even remotely alike. In this paper, several new genera are created in order to deal with these problems and all genera are rediagnosed.

\section{Key to Genera of LeUCONidAe}

1. Distinct eye lens and/or pigment present ............. 2

- Eyelobe without lens or pigment ..................... 3

2. Eyelobe extending to end of pseudorostrum, uropod endopod 2-articulate ................. Coricuma

- Eyelobe not reaching end of pseudorostrum, uropod endopod uniarticulate ...... Ommatoleucon 
3. Exopods on pereiopods 1 and 2 only in $\delta$ and $q$ Heteroleucon

- Exopods on pereiopods 1-3 in $\$$ and $1-4$ in $\delta$

4. Uropod endopod uniarticulate

- Uropod endopod 2-articulate

5. Pereiopod 2 article 3 <one-fourth as long as wide; o antenna 2 with seta brush on both anterior and posterior margins of peduncle article 5; ðे without pleopods .......... Austroleucon

- Pereiopod 2 article 3 half as long as wide; $\delta$ antenna 2 with seta brush only on anterior margin of peduncle articles 4 and 5 ; $\delta$ with 1 pair of pleopods Paraleucon

6. Efferent orifice anterior or anterodorsal ..

- Efferent orifice distinctly dorsal, pseudorostral lappets bent posteriad and directed dorsally

7. Pereiopod 2 article 3 nearly as long as wide Hemileucon

- Pereiopod 2 article 3 much shorter than wide or lost

8. Antenna 1 not geniculate or weakly geniculate

- Antenna 1 geniculate between peduncle articles 1 and 2

9. ô without pleopods, ô antenna 2 not reaching end of pereion Nippoleucon

- $\delta$ with 2 pairs of pleopods, ơ antenna 2 extending along pleon. Leucon

10. Uropod endopod and exopod subequal, anterolateral corner of carapace strongly angular Bytholeucon

- Uropod endopod much shorter than exopod, anterolateral corner of carapace obtuse Pseudoleucon

11. Antenna 1 geniculate between peduncle articles 1 and 2 Eudorellopsis

- Antenna 1 geniculate between peduncle articles 2 and 3 Eudorella

\section{Leucon Krøyer, 1846} Fig. 1

Epileucon Jones, 1956.

Type Species. -Cuma nasica Krøyer, 1841.

Diagnosis (emended). - Pseudorostrum projecting anteriorly, usually slightly shorter in male; antenna 1 not geniculate; male antenna 2 with brush of setae on anterior margin of peduncle articles 4 and 5; male antenna 2 flagellum extending well along pleon; female with exopods on pereiopods $1-3$; male with exopods on pereiopods 14 ; pereiopod 2 article 3 very short or lacking; uropod endopod 2-articulate; male with 2 pairs of pleopods.

\section{Key to Subgenera of LEUCON}

1. Branchial siphon elongate, greatly exceeding pseudorostrum Macrauloleucon

- Branchial siphon of normal length, protruding only slightly beyond pseudorostrum

2. Pereionite 5 with ventral hook(s) .............. Epileucon

- Pereionite 5 without ventral hook(s) ........................ 3

3. Antenna 1 accessory flagellum extending at least to midlength of main flagellum first article ... Crymoleucon

- Antenna 1 accessory flagellum short ..................... 4

4. Uropod endopod terminal seta fused to distal article Alytoleucon

- Uropod endopod terminal seta not fused to distal article Leucon

\section{COMPONENT SUBGENERA OF THE GENUS LEUCON}

Leucon Krøyer, 1846

Fig. 1a-c

Type Species. -Cuma nasica Krøyer, 1841.

Diagnosis. - Branchial siphon normal; antenna 1 accessory flagellum rudimentary; pereionite 5 without ventral teeth; uropod endopod terminal seta not fused to distal article.

Additional Species. - L. (L.) acutirostris Sars, 1865; L. (L.) affinis Fage, 1951; L. (L.) americanus Zimmer, 1943; L. (L.) armatus Given, 1961; L. (L.) assimilis Sars, 1887; L. (L.) fulvus Sars, 1865; L. (L.) homorhynchus Bishop, 1981 b; L. (L.) kobjakovae Lomakina, 1955 ; L. (L.) laticaudus Lomakina, 1952; L. (L.) magnadentatus Given, 1961; L. (L.) mediterraneus Sars, 1879; L. (L.) minor Lomakina, 1955; L. (L.) nasicoides Liljeborg, 1855; L. (L.) nathorsti Ohlin, 1901; L. (L.) panamensis Jones, 1969; L. (L.) profundus Hansen, $1920 ; L$. (L.) robustus Hansen, 1920; L. (L.) serratus Norman, 1879; L. (L.) simanensis Gamô, 1962; L. (L.) subnasica Given, 1961; L. (L.) varians Gamô, 1962.

\section{Key to Females of LEUCON (LEUCON)}

1. Uropod exopod clearly longer than endopod

- Uropod exopod shorter than or as long as endopod

2. Pereiopod 2 article 3 distinct ……............................... 3 Pereiopod 2 article 3 indistinct ............................ 5

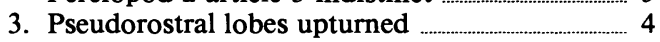

- Pseudorostral lobes directed horizontally .... americanus

4. Carapace with about 10 dorsal serrations anteriorly simanensis

- Carapace with about 4 dorsal serrations anteriorly varians

5. Carapace with dorsal serrations extending onto posterior one-third

- Carapace with dorsal serrations only on anterior two-thirds acutirostris 


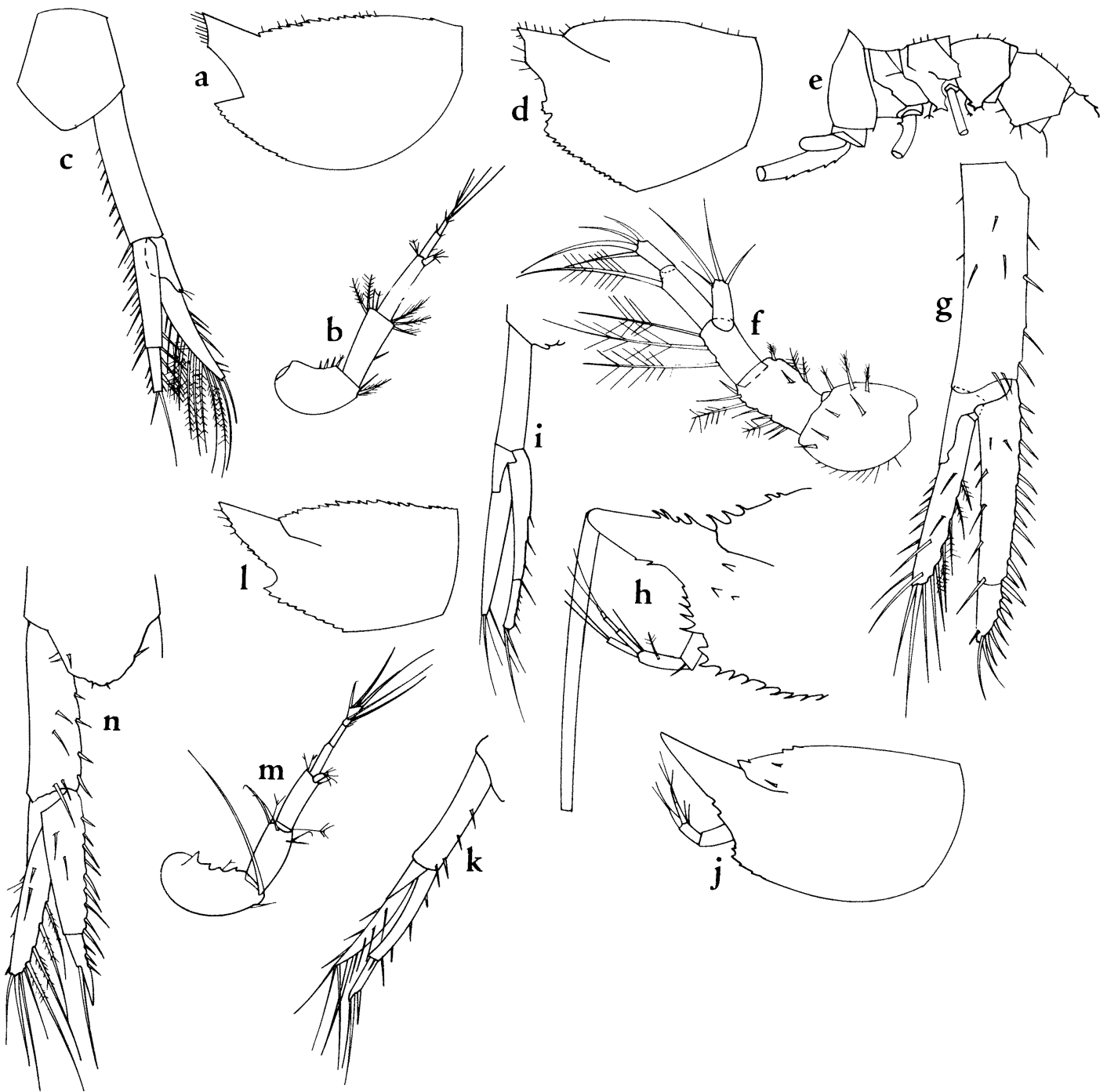

Fig. 1. Leucon (Leucon) nasica (from Sars, 1900): a, carapace, side view; b, antenna 1; c, uropod. Leucon (Epileucon) galatheae (from Bishop, 1981a): d, carapace, side view; e, pereionites 3-5 and pleonites 1 and 2; f, antenna 1; g, uropod. Leucon (Macrauloleucon) spinulosus (from Hansen, 1920): h, carapace and antenna 1; i, uropod. Leucon (Crymoleucon) tener (from Hansen, 1920): j, carapace and antenna 1; k, uropod. Leucon (Alytoleucon) medius (from Bishop, 1982): 1, carapace, side view; m, antenna 1; n, uropod. (Drawings not to same scale.)

6. Carapace with dorsolateral spines on frontal lobe robustus

- Carapace without dorsolateral spines on frontal lobe

7. Pereiopod 1 article 5 longer than article 6

- Pereiopod 1 articles 5 and 6 subequal in length

8. Uropod endopod broadened ......................... laticauda

- Uropod endopod normally elongate

9. Pereiopod 2 article 3 present panamensis

- Pereiopod 2 article 3 not present 10

10. Pseudorostral lobes subtriangular to acute distally, carapace with dorsal serrations absent from posterior third
- Pseudorostral lobes subquadrate (blunt) distally, carapace with dorsal serrations throughout length

11. Pereiopod 1 basis with large serrations magnadentata

- Pereiopod 1 basis without large serrations ....... 12

12. Pereiopod 1 basis with several plumose setae along margin subnasica

- Pereiopod 1 with few setae of any kind along margin minor

13. Uropod peduncle shorter than endopod armatus

- Uropod peduncle as long as endopod .................. 14

14. Carapace and following pereionites strongly 
convex dorsally

- Carapace and following pereionites not arched dorsally kobjakovae

15. Antenna 1 peduncle article 3 at least as long as main flagellum

- Antenna 1 peduncle article 3 shorter than main flagellum

16. Uropod exopod extending only to distal margin of endopod basal article ...................... profundus

- Uropod endopod extending beyond distal margin of endopod basal article

17. Carapace with dorsolateral tooth behind frontal lobe nathorsti

- Carapace without this tooth

18. Uropod exopod inner margin with numerous $(>10)$ setae nasicus

- Uropod exopod inner margin lightly $(<9)$ se-

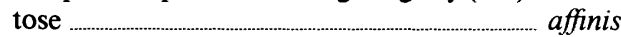

19. Uropod peduncle inner margin heavily setose along length ................................................

- Uropod peduncle inner margin sparsely setose

20. Pereiopod 2 article 4 with strong seta at distal corner assimilis

- Pereiopod 2 article 4 with at most 1 plumose seta at distal corner

21. Uropod exopod with dense cluster of long setae distally homorhynchus

- Uropod exopod sparsely setose distally ....... fulvus

\section{Epileucon Jones, 1956}

Fig. 1d-g

Type Species. -Epileucon galatheae Jones, 1956.

Diagnosis (emended). - Branchial siphon normal; antenna 1 accessory flagellum at least half length of main flagellum first article; pereionite 5 with at least 1 pair of ventral teeth or single midventral tooth; uropod endopod terminal seta not fused to distal article.

Additional Species. - L. (E.) acclivis (Bishop, 1981a); L. (E.) bengalensis Lomakina, 1967; L. (E.) craterus (Bishop, 1981a); $L$. (E.) ensis (Bishop, 1981a); L. (E.) kalluropus Stebbing, 1912; L. (E.) latispina Jones, 1963; L. (E.) longirostris Sars, 1871; L. (E.) pusillus (Bishop, 1981a); L. (E.) socius (Bishop, 1981a); L. (E.) spiniventris Hansen, 1920; L. (E.) tenuirostris Sars, 1887.

\section{Key to Females of LEUCoN (EPILEUCON)}

(abbreviated and emended from Bishop, 1981a)

1. Pseudorostrum long $(\ll 0.5$ times carapace length)
- Pseudorostrum relatively short $(<<0.5$ times carapace length)

2. Pseudorostral lobes distally subacute tenuirostris

- Pseudorostral lobes distally bluntly rounded

3. Sternite of fifth pereionite with at least 4 spiniform teeth ensis

Sternite of fifth pereionite with 1 or 2 spini-

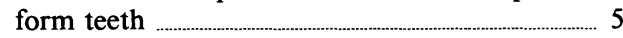

4. Peduncle of uropod with 3 or 4 setae on medial margin

- Peduncle of uropod with 5-8 setae on medial margin ............................................... spiventris

5. Sternite of fifth pereionite with single midventral tooth …...................................... kalluropus

- Sternite of fifth pereionite with paired teeth

6. Uropod exopod longer than endopod basal article

- Uropod exopod shorter than endopod basal article 5

7. Pereiopod 1 dactylus about one-half length of propodus

- Pereiopod 1 dactylus about two-thirds length

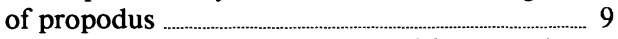

8. Carapace anteroventral corner with protruding tooth .................................................

- Carapace anteroventral corner indistinct, marked by a sinus ..................................... latispina

9. Pereiopod 2 dactylus with 3 or 4 plumose se-

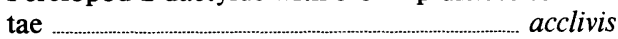

- Pereiopod 2 dactylus with more than 6 plumose setae .......................................... socius

10. Pereionite 4 pleural plate with ventrally directed tooth ................................................... pusillus

- Pereionite 4 pleural plate ventrally rounded

11. Pereiopod 2 article 5 with several $(>4)$ plumose setae ............................................. crate

- Pereiopod 2 article 5 with 1 or 2 plumose setae longirostris

\section{Macrauloleucon, new subgenus} Fig. 1h, i

Type Species. - Leucon spinulosus Hansen 1920.

Etymology. - Combination of Greek makros, long, aulos, pipe tube, and leucon, the stem genus, referring to the unusually long branchial siphon exhibited by these species.

Diagnosis. - Branchial siphon greatly elongate; antenna 1 accessory flagellum extending beyond midlength of main flagellum first article; pereionite 5 without ventral teeth; uropod endopod terminal seta not fused with distal article.

Additional Species. - L. (M.) siphonatus Calman, 1905; L. (M.) stenorhynchus Gamô, 1988. 


\section{Key to SPECIES OF LEUCON (MACRAULOLEUCON)}

1. Pseudorostrum and frontal lobe with long spines

- Pseudorostrum with low spines, none on frontal lobe siphonatus

2. Pereionites 2 and 3 with dorsal and dorsolateral spines ............................................ spinulosus

- Pereionites 2 and 3 without spines stenorhynchus

Crymoleucon, new subgenus

Fig. 1j, k

Type Species. - Leucon tener Hansen, 1920.

Etymology. - From Greek krymos, icy cold, for the waters in which the members of this subgenus are found or appear to have been derived, and leucon, the stem genus.

Diagnosis. - Branchial siphon normal; antenna 1 accessory flagellum extending at least to midlength of main flagellum first article; pereionite 5 without ventral teeth; uropod endopod terminal seta not fused to distal article.

Additional Species. - L. (C.) antarcticus Zimmer, 1907; L. (C.) bishopi Băcescu, 1988; L. (C.) dayae Ledoyer, 1988; L. (C.) heterostylis Calman, 1907a; L. (C.) inexcavatus Ledoyer, 1977; L. (C.) kerguelensis Zimmer, 1908; L. (C.) macrorhinus Fage, 1951; L. (C.) sagitta Hansen, 1920; L. (C.) septemdentatus Zimmer, 1902; L. (C.) serrulirostris Ledoyer, 1988; L. (C.) vanhoeffeni Zimmer, 1907.

\section{Key to Females of LEUCON (CRYMOLEUCON)}

1. Antenna 1 accessory flagellum extending well beyond main flagellum basal article

- Antenna 1 accessory flagellum equal in length or shorter than main flagellum basal article ......... 4

2. Uropod exopod shorter than endopod basal article heterostylis

- Uropod exopod equal to or longer than endopod basal article

3. Antennal notch obsolete; carapace middorsal teeth not extending to posterior margin

inexcavatus

- Antennal notch strong; carapace middorsal teeth continuous from eyelobe to posterior margin

4. Pseudorostral lobes greatly elongated antarcticus

- Pseudorostral lobes of normal length

5. Pereiopod 1 elongate, article 6 at least twice length of article 7; pseudorostrum with fringe of long setae

- Pereiopod 1 stout, article 6 slightly shorter than article 7; pseudorostrum without long fringe of setae
6. Carapace antennal notch defined ventrally by 2 large teeth macrorhinus

- Carapace antennal notch indistinct, anteroventral margin with very small serrations

serrulirostris

7. Uropod exopod extending well beyond endopod dayae

- Uropod exopod equal to or shorter than endopod

8. Uropod exopod extending only to end of endopod basal article

- Uropod exopod at least equal to entire endopod (complex representing sagitta, vanhoeffeni, and kerguelensis)

9. Antennal notch strong; pereiopod 1 article 7 more than three-fourths length article 6 septemdentatus

- Antennal notch obsolescent; pereiopod 1 article 7 about one-half length article 6 ......... bishopi

\section{Alytoleucon, new subgenus}

Fig. 11-n

Type Species. -Leucon jonesi Bishop, 1982. Etymology. - From Greek alytos, continuous, unbroken, referring to the fused condition of the uropod endopod terminal seta, and leucon, the stem genus.

Diagnosis. - Branchial siphon normal; accessory flagellum rudimentary; pereionite 5 without ventral teeth; uropod endopod terminal seta fused to distal article.

Additional Species. - L. (A.) medius Bishop, 1982; L. (A.) pallidus Sars, 1865; L. (A.) turgidulus Bishop, 1982.

\section{Key to SPECIES OF LEUCON (ALYTOLEUCON)}

1. Pereiopod 1 compact, article 41.5 times length of article 3 pallidus

- Pereiopod 1 elongate, article $4>3$ times length article 3

2. Pereiopod 1 exopod articles not reaching distal end of basis .................................... turgidulus

- Pereiopod 1 exopod articles extending beyond distal end of basis

3. Pereiopod 1 article 7 slightly shorter than article 6; pereiopod 3 articles 4 and 5 subequal .... medius

- Pereiopod 1 articles 6 and 7 subequal; pereiopod 3 article $5>4$ jonesi

Remarks. - The genus Epileucon was originally created by Jones (1956) for the species $E$. galatheae, which had the characters of the genus Leucon, but differed from all known species by the absence of a serrated dorsal crest. Bishop (1981a) noted that some specimens of $E$. galatheae in fact possessed several small dorsal teeth or serrations on 
the carapace. He stated "the supposed distinction between Epileucon and Leucon is therefore eroded" (p. 354). Bishop then redefined the genus Epileucon, using as the primary character the presence of ventral teeth on pereionite 5 . In addition, many other characters were listed, the combination of which was considered to be unique to species of Epileucon. However, any one or more, but not all, of these characters could be found in some species of Leucon. Băcescu (1988) rejected the genus Epileucon, suggesting that the additional features provided by Bishop were not significant at the generic level and were not to be seen on all the species presumed to constitute the genus. Instead, he divided the species of Leucon into two subgenera, Leucon and Epileucon, depending on whether or not they possessed ventral teeth on pereionite 5. Bishop (1981a) reexamined several species and the details mentioned above regarding the presence or absence of ventral teeth are taken from his paper. On this basis, L. bishopi is moved out of the subgenus Epileucon. In this paper, other subgenera are proposed which reflect the common possession of selected features by groups of species of Leucon. In each case, it is not felt that these features are of sufficient significance to warrant the erection of new genera, but rather are hypothesized as representing evolutionary patterns within the genus. However, it is possible that the features used to diagnose each subgenus will be found to be homoplasious upon the discovery of additional species.

Ommatoleucon, new genus Fig. 2a-e

Type Species. - Leucon ocularis Hale, 1945. Etymology. - From Greek ommatos, eye, referring to the presence of a lens on the eyelobe, and leucon, the stem genus.

Diagnosis. - Pseudorostrum projecting anteriorly, slightly shortened in male; antenna 1 weakly geniculate between peduncle articles 1 and 2 ; male antenna 2 with brush of setae on anterior margin of peduncle articles 4 and 5; male antenna 2 flagellum extending well along pleon; female with exopods on pereiopods $1-3$; male with exopods on pereiopods $1-4$; pereiopod 2 article 3 much shorter than wide in male, lost in female; uropod endopod uniarticulate; male with 2 pairs of pleopods; pigmented eye with single lens present in both sexes.

Additional Species. - No others.

Remarks. - The presence of a pigmented eye with a lens distinguishes this genus from all other members of the family. Ommatoleucon ocularis was originally placed in the genus Leucon principally on the basis of its general body shape and the presence of two pairs of pleopods in the male. Its eye and the uniarticulate uropod endopod also made it unique among the members of Leucon.

\section{Hemileucon Calman, 1907}

Fig. $2 \mathrm{f}-\mathrm{i}$

Type Species. - Hemileucon uniplicatus Calman, 1907a.

Diagnosis. - Pseudorostrum projecting anteriorly, shorter in male; antenna 1 geniculate between peduncle articles 1 and 2; male antenna 2 with brush of setae on anterior margin of peduncle articles 4 and 5; male antenna 2 flagellum not extending beyond pereion; female with exopods on pereiopods $1-3$; male with exopods on pereiopods $1-$ 4 ; pereiopod 2 article 3 distinct; uropod endopod 2-articulate; male without pleopods.

Additional Species. - H. comes Calman, 1907a.

\section{Key tO THE SPECIES OF HEMILEUCON}

1. Carapace with lateral ridge extending forward from near posterior margin to beginning of pseudorostral lobes; pseudorostral lobes not upturned uniplicatus

- Carapace with oblique lateral ridge extending dorsoventrally; pseudorostrum upturned in $q$

comes

\section{Austroleucon, new genus}

Fig. $2 \mathrm{j}-\mathrm{m}$

Type Species. - Hemileucon levis Hale, 1945. 1945.

Etymology.-Austr-, from Australia, and leucon, the stem genus.

Diagnosis. - Pseudorostrum projecting anteriorly, equal in male and female; antenna 1 slightly geniculate between peduncle articles 1 and 2; male antenna 2 with brush of setae on anterior margin of peduncle article 5 and posterior margins of peduncle articles 4 and 5; male antenna 2 flagellum 


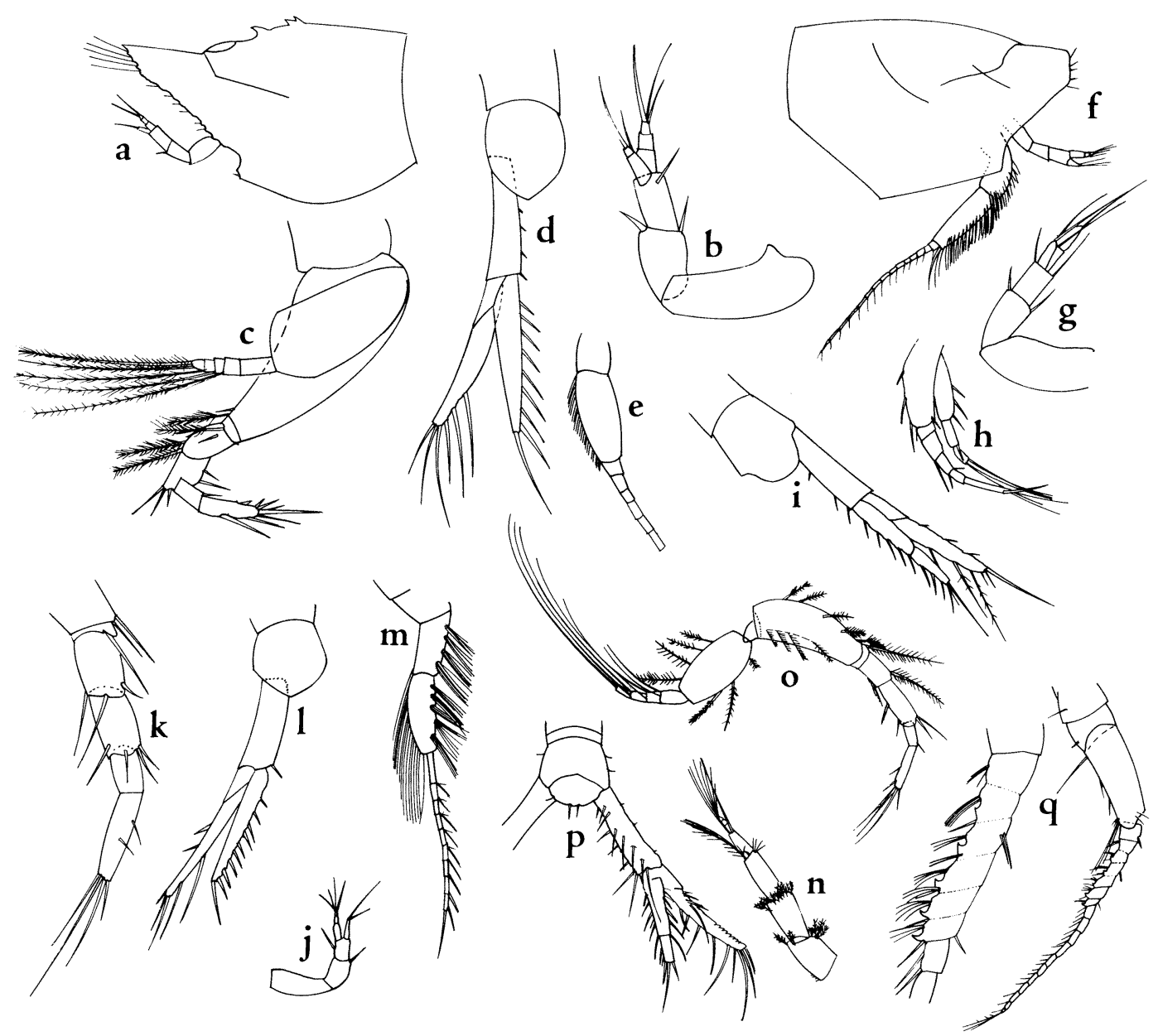

Fig. 2. Ommatoleucon ocularis (from Hale, 1945): a, carapace, side view; b, antenna 1; c, pereiopod 2; d, uropod; e, ô antenna 2 peduncle and proximal flagellar aricles. Hemileucon comes (from Calman, 1907a); f, ô carapace, side view, and antenna 1 and 2; g, antenna 1; h, pereiopod 2; i, uropod. Austroleucon levis (from Hale, 1945): j, antenna 1; k, pereiopod 2; 1, uropod; m, ô antenna 2. Nippoleucon hinumensis (from Gamô, 1967): $n$, antenna 1; o, pereiopod 2; p, uropod; q, ô antenna 2 with detail of basal flagellar structure. (Drawings not to same scale.)

not extending beyond pereion; female with exopods on pereiopods $1-3$; male with exopods on pereiopods $1-4$; pereiopod 2 article 3 much shorter than wide; uropod endopod uniarticulate; male without pleopods.

Additional Species. - No others.

Remarks. - Austroleucon levis was originally placed in the genus Hemileucon on the basis of its lack of pleopods and shortened antenna 2 flagellum. The form of antenna 2, however, differs from that seen in the species of Hemileucon. The latter have a typical male antenna 2 with a strong brush of setae on the anterior margin of peduncle articles 4 and 5 . Such a setal orientation assures the reception of sensory information while the male is swimming through the water. In Austroleucon the setal brush on the anterior margin of peduncle articles 4 and 5 is augmented by a strong brush on the posterior margin of peduncle article 5. A change in the function of antenna 2 during the mate pursuit process seems likely. Additionally, Austroleucon differs from Hemileucon by its possession of a uniarticulate uropod endopod.

Nippoleucon, new genus Fig. $2 n-q$

Type Species. - Hemileucon enoshimensis Gamô, 1967. 
Etymology. - Nippon-, from Japan, and leucon, the stem genus.

Diagnosis. - Pseudorostrum projecting anteriorly, shorter in male; antenna 1 not geniculate; male antenna 2 without brush of setae on peduncle articles 4 and 5 , peduncle article 5 subdivided by several annulations, each division with grasping tooth and setal bundle on posterior margin; male antenna 2 flagellum not extending beyond carapace posterior margin; female with exopods on pereiopods $1-3$; male with exopods on pereiopods $1-4$; pereiopod 2 article 3 very short; uropod endopod 2-articulate; male without pleopods.

Additional Species. - N. hinumensis (Gamô, 1967).

Remarks. - The two species assigned to this genus were originally placed in the genus Hemileucon. Continuing the modification of the male antenna 2 seen in Austroleucon, in Nippoleucon the peduncular articles have become modified into grasping-like structures. The brush of setae is completely missing from peduncular articles 4 and 5; peduncle article 5 is ringed with several annulations, each subdivision bearing a recurved flexible tooth and a small cluster of setae; the flagellum is still present but consists of less than 12 articles.

\section{KeY to SPECIES OF NIPPOLEUCON}

1. Uropod exopod inner margin with plumose setae; carapace and appendages generally devoid of scales ........................................... enoshimensis

- Uropod exopod inner margin with long simple setae; carapace and appendages generally covered with scales hinumensis

Coricuma Watling and Breedy, 1988

Type Species. - Coricuma nicoyensis Watling and Breedy, 1988.

Diagnosis (emended). - Pseudorostrum projecting anteriorly, slightly shorter in male; antenna 1 not geniculate; male antenna 2 peduncular articles 4 and 5 without brush of setae, article 5 annulated and possessing grasping teeth; male antenna 2 flagellum absent; female with exopods only on pereiopod 1; male with exopods only on pereiopod 1; pereiopod 2 article 3 lost; uropod endopod 2-articulate; male with 2 pairs of pleopods; carapace with distinct eyelobe projecting anteriorly over pseudorostral lobes.

Additional Species. - No others.

Remarks.-Since this species seemed to have the characters of both the Bodotriinae and the Leuconidae, it was tentatively assigned to the former by Watling and Breedy (1988). However, many of the features it exhibits are the result of reductions and I have felt it necessary to reevaluate its placement. In particular, the number of exopods is reduced, the mandible has no molar, and there are only 6 articles in pereiopod 3 . On the basis of the presence of a strongly developed eyelobe and the reduced number of exopods, the genus was placed in the Bodotriinae. On the other hand, the number of pleopods, the lack of an internal process on the pleopod inner ramus, and truncate mandible (not elongate as originally described), could have justified its placement in the Leuconidae. While the strongly developed eyelobe remains a problem, and certainly necessitates a reevaluation of the characters defining the family, the high degree of similarity of the male antenna 2 grasping structure to that seen in Nippoleucon suggests strong affinities to the Leuconidae. A reduced male antenna 2 is seen in other families, for example, in the Lampropidae (e.g., Lamprops [see Sars, 1900]), and Bodotriidae Mancocuminae (Spilocuma Watling, 1977). In both Lamprops and Spilocuma the antennal modifications are on the anterior margin, whereas in Nippoleucon and Coricuma the grasping structures are modifications of the posterior margin, suggesting that this function for the antennae has arisen independently.

\section{Heteroleucon Calman, 1907a Fig. 3a-d}

Type Species. - Heteroleucon akaroensis Calman, 1907a.

Diagnosis. - Pseudorostrum projecting anterodorsally, shorter in male; antenna 1 weakly geniculate between peduncle articles 1 and 2; male antenna 2 with brush of setae on anterior margin of peduncle articles 4 and 5; male antenna 2 flagellum not extending beyond posterior margin of carapace; female with exopods on pereiopods 1 and 2; male with exopods on pereiopods 1 


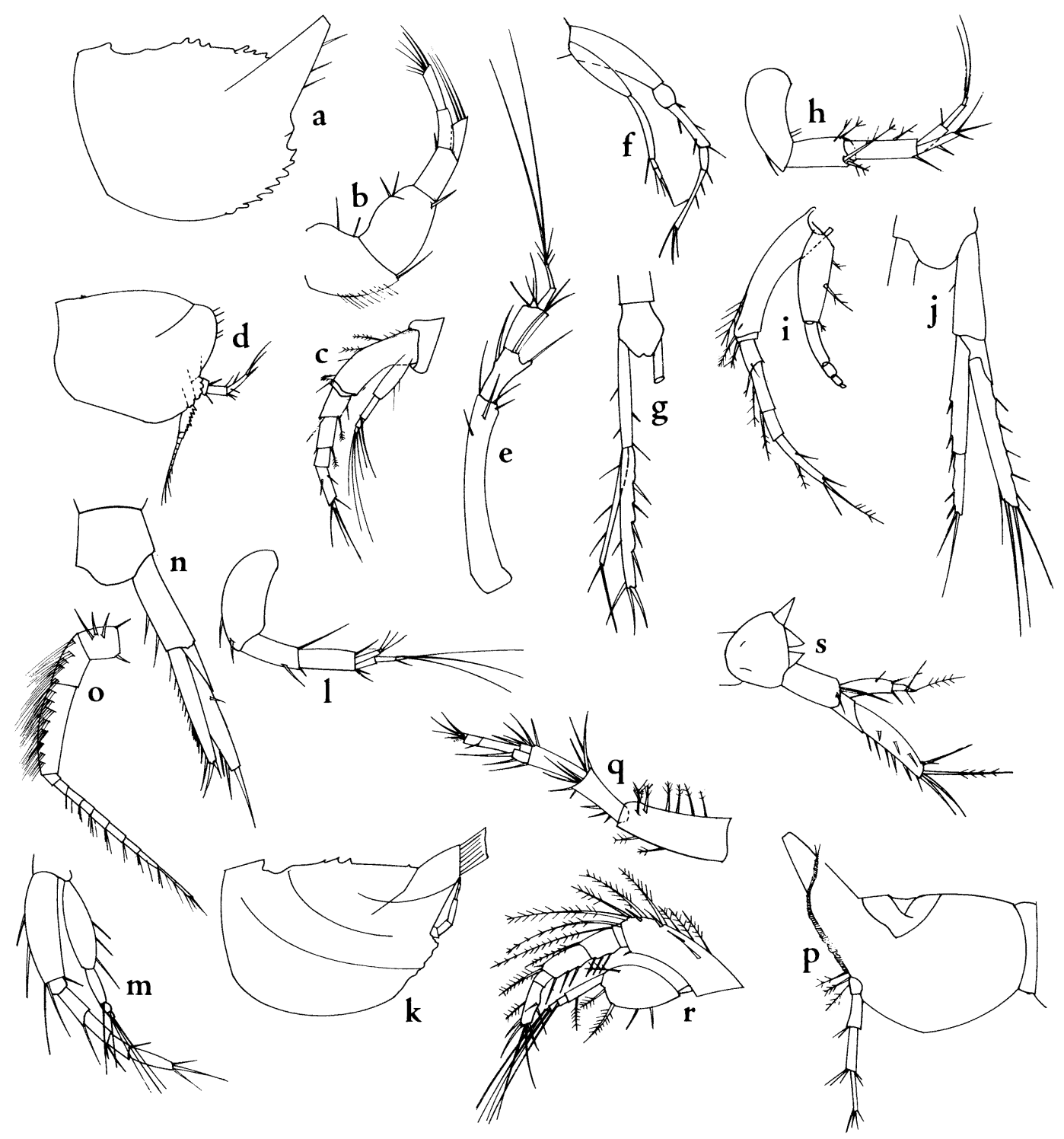

Fig. 3. Heteroleucon akaroensis (from Calman, 1907a): a, \& carapace, side view; b, antenna 1; c, pereiopod 2; d, ô carapace, side view, and antennae 1 and 2. Americuma heardi (from Băcescu, 1979): e, antenna 1; f, pereiopod 2; g, uropod. Bytholeucon hiscens (from Bishop, 1981b): h, antenna 1; i, pereiopod 2; j, uropod. Paraleucon suteri (from Calman, 1907a): k, carapace, side view; 1 , antenna 1; m, pereiopod 2; n, uropod; o, ô antenna 2. Pseudoleucon japonicus (from Gamô, 1964): p, carapace, side view; $q$, antenna 1; r, pereiopod 2; s, uropod. (Drawings not to same scale.)

and 2; pereiopod 2 article 3 short; uropod endopod uniarticulate; male without pleopods.

Additional Species. - No others.

Remarks. - A male from the Natural History Museum, London (BMNH.1907. viii.27.79), with fully developed antenna 2 was examined. The setal brush was seen to consist of setae arranged in five distinct rows on article 4 and 6 rows on article 5 . Each row extended only slightly from the anterior onto the lateral margin of the peduncle article and did not appear to be present on the medial margin.

\section{Bytholeucon, new genus}

Fig. $3 \mathrm{~h}-\mathrm{j}$

Type Species. - Paraleucon (?) hiscens Bishop, $1981 b$. 
Etymology. - From Greek bythos, the depths of the sea, and leucon, the stem genus.

Diagnosis. -Pseudorostrum projecting anteriorly, slightly shorter in male; antenna 1 geniculate between peduncle articles 1 and 2 ; antenna 2 of mature male unknown but in immature male brush of seta seen developing on anterior margin of peduncle articles 4 and 5; antenna 2 flagellum elongate in immature male; female with exopods on pereiopods $1-3$; male with exopods on pereiopods $1-4$; pereiopod 2 article 3 very short; uropod endopod distinctly 2 -articulate; subadult male with (?)0 or 1 pair of pleopods.

Additional Species. - B. ultraabyssalis (Gamô, 1987).

Remarks. - Bytholeucon hiscens was tentatively assigned to Paraleucon by Bishop (1981b) on the basis of the late appearance of a single pair of pleopods in the one male known that is mature enough to show definitive characters. Besides the very great geographic and depth differences in the distribution of Paraleucon suteri (shallow waters of New Zealand) and the species of $B y$ tholeucon (deep sea in the Atlantic and Pacific), the latter are distinguished also by the long antenna 2 flagellum in the male and short pereiopod 2 article 3 . When a mature male is found, the relationship of Bytholeucon to Paraleucon can be better assessed.

\section{Key to SPECIES OF BYTHOLEUCON}

1. Uropod peduncle shorter than basal article of endopod; basal article of pereiopod 1 exopod with 2 separated spines hiscens

- Uropod peduncle longer than basal article of endopod; basal article of pereiopod 1 exopod with 4 closely set spines ultraabyssalis

\section{Paraleucon Calman, 1907a}

Fig. 3k-0

Type Species. - P. suteri Calman, 1907a.

Diagnosis. -Pseudorostrum extending anteriorly, shorter in male; antenna 1 weakly geniculate between articles 1 and 2; male antenna 2 with brush of setae on anterior margin of peduncle articles 4 and 5; male antenna 2 flagellum short; female with exopods on pereiopods $1-3$; male with exopods on pereiopods $1-4$; pereiopod 2 article 3 distinct, nearly as long as wide; uropod endopod uniarticulate; male with 1 pair of pleopods.

Additional Species. - No others.

Remarks. -Specimens on slides 1907. viii.29.135 and 1907.viii.29.136 in the collection of the Natural History Museum, London, were examined. In neither case was it possible to see the slight crease that Calman suggested was present on the uropod endopod. Consequently, the uropod endopod must be considered to be uniarticulate.

\section{Pseudoleucon Zimmer, 1903} Fig. 3p-s

Type Species.-Pseudoleucon sorex Zimmer, 1903.

Diagnosis. - Pseudorostrum extending anterodorsally, (male ?); antenna 1 geniculate between articles 1 and 2; (? male antenna 2 brush of setae on anterior margin of peduncle articles 4 and 5); (? male antenna 2 flagellum elongate); female with exopods on pereiopods 1-3; male with exopods on pereiopods $1-4$; pereiopod 2 article 3 narrow; uropod endopod 2-articulate; male with 2 pairs of pleopods.

Additional Species. -P. japonicus Gamô, 1964.

Remarks. - While both sexes are known for $P$. sorex, the male is incompletely described and needs to be reexamined.

\section{KEY TO THE SPECIES OF PSEUDOLEUCON}

1. Carapace with forwardly directed oblique ridge extending from dorsal margin to posterior limit of pseudorostral lobe japonicus

- Carapace without oblique ridge ……………………... sorex

\section{Eudorella Norman, 1867}

Type Species. - Eudora truncatula Bate, 1856.

Diagnosis. - Pseudorostrum directed dorsally in both male and female; antenna 1 geniculate between peduncle articles 2 and 3 ; male antenna 2 with brush of setae on anterior margin of peduncle articles 4 and 5 ; male antenna 2 flagellum extending nearly to end of pleon; female with exopods on pereiopods $1-3$; male with exopods on pereiopods $1-4$; pereiopod 2 article 3 lost; uropod endopod 2-articulate; male with 2 pairs of pleopods. 
Additional Species. -E. abyssi Sars, 1887; $E$. aequiremis Hansen, 1920; E. arctica Hansen, 1920; E. dentata Lomakina, 1955; E. emarginata (Krøyer, 1846); E. fallax Zimmer, 1909; E. gottliebi Băcescu, 1961; E. gracilior Zimmer, 1907; E. gracilis Sars, 1871; E. groenlandica Zimmer, 1926; E. hirsuta (Sars, 1869); E. hispida Sars, 1871; $E$. hurleyi Jones, 1963; E. intermedia Hansen, $1920 ; E$. minor Lomakina, 1952; $E$. monodon Calman, 1912; E. nana Sars, 1879; $E$. pacifica Hart, 1930; E. parvula Hansen, 1920; E. pusilla Sars, 1871; E. rochfordi Hale, 1945; E. similis Calman, 1907b; $E$. sordida Zimmer, 1907; E. spitzbergensis Zimmer, 1926; E. splendida Zimmer, 1902; E. tridentata Hart, 1930.

Remarks. - There are several pairs, or groups, of closely related species in this genus. While Băcescu (1988) considered $E$. difficilis Blake, 1929, to be a good species, Watling (1979) suggested it was probably synonymous with $E$. pusilla. Since the type of $E$. difficilis has been lost, this issue may never be fully resolved. My own collections from the type locality, however, have produced no specimens that differ from the $E$. pusilla collected elsewhere on the east coast of the United States. Other very closely related species pairs include: $E$. gracilior and $E$. sordida (from South Georgia); E. groenlandica and $E$. spitzbergensis (Greenland, and Kara and Laptev Seas, respectively); $E$. gracilis and $E$. parvula (Spitsbergen and the Davis Straits, respectively); $E$. splendida and $E$. similis (Antarctic and Subantarctic, respectively); and $E$. pacifica and $E$. tridentata (boreal Pacific). Several species appear to be very close to $E$. truncatula, namely, $E$. intermedia (Davis Strait to Bay of Biscay, 2,000-5,000 m), E. gottliebi (eastern Mediterranean, 49-238 m), and E. nana (Mediterranean, 37-300 m). The distributions of the latter three species lie well within the geographic range from which $E$. truncatula has been recorded. Clearly, there is a problem with closely related species in this genus. Since the variability in none of these species has been studied, the validity of the closely related species cannot be assessed.

\section{Key to Females of EUdorella}

1. Uropod endopod terminal seta articulated with distal article
- Uropod endopod terminal seta fused to terminal article 14

2. Uropod rami equal in length ….......... aequiremis

- Uropod exopod at least slightly shorter than endopod

3. Uropod exopod much shorter than endopod basal article 3 Uropod exopod about as long as or longer than endopod basal article 4 Carapace anteroventral corner with strong downward pointing tooth above sinus .... dentata Carapace anteroventral corner with smooth or microdentate lobe above sinus

5. Pereiopod 1 article 6, 5-6 times as long as wide, antennule both flagella with naked margins gracilior $^{1}$

- Pereiopod 1 article 6, 2-3 times as long as wide, antennule accessory flagellum with plumose setae distally on margin fallax

6. Antennule accessory flagellum at least as long as main flagellum basal article

Antennule accessory flagellum shorter than main flagellum basal article

7. Carapace pseudorostral lobes with many long setae; antennule accessory flagellum threefourths length of main flagellum basal article hirsuta

- Carapace pseudorostral lobes with few short setae; antennule accessory flagellum less than one-half length main flagellum basal article monodon

8. Uropod exopod clearly longer than endopod basal article

- Uropod exopod only as long as endopod basal article

9. Uropod endopod terminal seta much longer than ( $>2$ times) terminal article; pereiopod 2 dactyl with setae only on distal one-third hurleyi

- Uropod endopod terminal seta equal in length to terminal article; pereiopod 2 dactyl with setae on distal two-thirds

10. Uropod peduncle with long, slender terminal seta between insertion of endopod and exopod; exopod with at least 7 setae on inner margin in adult groenlandica ${ }^{2}$

- Uropod peduncle without long slender terminal seta; exopod with only 3 or 4 setae on inner margin in adult .............................. racilis $^{3}$

11. Antennule peduncle article 2 at least 1.5 times length article 3

- Antennule peduncle articles 2 and 3 subequal in length

12. Uropod exopod narrow, elongate, without submarginal setae, marginal setae plumose abyssi

- Uropod exopod slightly broadened, submarginal setae present, marginal setae not plumose splendida ${ }^{4}$

13. Antennule main flagellum basal article with plumose setae, pereiopod 2 article 5 subequal to article 4 minor

- Antennule main flagellum basal article naked on margins, pereiopod 2 article 5 about 1.5 times length article 4 pacifica $^{5}$

14. Uropod exopod distinctly shorter than endopod basal article 
- Uropod exopod about as long as or longer than endopod basal article

15. Antennule main flagellum with plumose setae on lateral margin; anteroventral corner of carapace with single large sinus; pereiopod 2 terminal article with many more than 12 setae emarginata

- Antennule main flagellum naked; ventrolateral corner of carapace with 2 small sinuses; pereiopod 2 terminal article with less than 12 setae

16. Uropod exopod extending to end of endopod distal article arctica

- Uropod exopod only slightly longer than endopod basal article

17. Body more or less beset with fine setae; pseudorostral lobes with numerous long setae; pereiopod 2 article 5 about 1.5 times as long as article 4 hispida

- Body more or less free of fine setae; pseudorostral lobes without numerous long setae; pereiopod 2 articles 4 and 5 subequal .... truncatula $^{6}$

Notes: ${ }^{1}$ Includes $E$. sordida. ${ }^{2}$ Includes $E$. spitzbergensis. ${ }^{3}$ Includes $E$. parvula. ${ }^{4}$ Includes $E$. similis. ${ }^{5}$ Includes $E$. tridentata. ${ }^{6} E$. intermedia, E. gottliebi, and $E$. nana may all be variants of $E$. truncatula. The key also does not consider $E$. rochfordi as the details of its uropod endopod are not known.

\section{Eudorellopsis Sars, 1882}

\section{Type Species. - Leucon deformis Krøyer,} 1846.

Diagnosis. - Pseudorostrum directed dorsally in both male and female; antenna 1 geniculate between peduncle articles 1 and 2 ; male antenna 2 with brush of setae on anterior margin of peduncle articles 4 and 5 ; male antenna 2 flagellum extending well along pleon; female with exopods on pereiopods 1-3; male with exopods on pereiopods $1-4$; pereiopod 2 article 3 lost; uropod endopod 2-articulate; male with 2 pairs of pleopods.

Additional Species. - E. biplicata Calman, 1912; E. derzhavini Lomakina, 1952; E. integra (Smith, 1879); E. longirostris Given, 1961; E. resima Calman, 1907b; E. uschako$v i$ Lomakina, 1955.

\section{Key to Females of Eudorellopsis}

1. Carapace with lateral horizontal or oblique ridge

- Carapace without lateral ridge ………............................ 2

2. Uropod exopod rectangular with no setae on outer margin; pseudorostral lobes extending somewhat forward, not strictly vertical; carapace more elongate, longer than high .......... integra

- Uropod exopod tapering, with setae along outer margin; pseudorostral lobes strictly vertical; carapace boxlike, as long as high deformis
3. Carapace with single, nearly horizontal ridge; terminal seta of uropod endopod 2 times longer than distal article resima

- Carapace with 2 obliquely curving ridges; uropod endopod terminal seta as long as or shorter than distal article

4. Uropod exopod distal article expanded, widest midway along its length; endopod basal article nearly devoid of setae derzhavini

- Uropod exopod distal article of normal construction, gradually tapering distally; endopod basal article with lateral setae

5. Carapace with anterolateral horns; pleotelson terminally triangular

- Carapace without anterolateral horns; pleotelsonic somite broadly rounded posteriorly

\section{biplicata}

6. Uropod endopod with few setae on inner margin, distal article with no marginal setae; pseudorostral lobes with especially long setae ushakovi

- Uropod endopod with setae along entire length of inner margin, including on distal article; pseudorostral lobes with few short setae

longirostris

\section{INCERTAE SEDIS}

Americuma, new genus

Fig. $3 \mathrm{e}-\mathrm{g}$

Type Species. - Heteroleucon heardi Băcescu, 1979.

Etymology.-Amer-, from America, and cuma, the stem group.

Diagnosis. - Pseudorostrum projecting anterodorsally, branchial siphon long; antenna 1 not geniculate; female with exopods on pereiopods 1 and 2 ; pereiopod 2 article 3 distinct; uropod endopod uniarticulate; male unknown.

Additional Species. - No others.

Remarks. - This species, described from a manca, was originally assigned to the genus Heteroleucon. However, it differs from the only other species of Heteroleucon, $\mathrm{H}$. akaroensis from New Zealand, in several important respects: its antenna 1 peduncle article 1 is very elongate, being as long as the remaining articles combined; it has a distinct, elongate pereiopod 2 article 3 ; there is no antennal notch on the carapace; and article 3 of maxilliped 3 is greatly enlarged. Further, it was obtained half a world away and at considerably greater depth, thus requiring the relating of two species in a manner which would be almost unique among the Cumacea. There is no strong evidence that this species is, in fact, a member of the Leuconidae; it has been dealt with here as 
a means of maintaining order within the genera of this family.

\section{ACKNOWLEDGEMENTS}

This study was conducted during the tenure of a Smithsonian Senior Postdoctoral Fellowship, for which the support of the Smithsonian Institution is greatly appreciated. I especially thank Dr. T. E. Bowman for critically reading an earlier version of this paper and for helping me to understand the broader concepts of taxonomy. The illustrations were prepared by S. Bund.

\section{LITERATURE Cited}

Băcescu, M. 1961. Contribution à l'étude des Cumacés de la Méditerranée et particulièrement des côtes d'Israel. - Rapports et Procès-verbaux des Réunions de la C.I.E.S.M.M. 16: 495-502.

. 1979. Heteroleucon heardi $\mathrm{n}$. sp. from the Mexican Gulf. - Revue Roumaine de Biologie (série Biologie animale) 24: 95-97.

-1 1988. Cumacea I (Fam. Archaeocumatidae, Lampropidae, Bodotriidae, Leuconidae). -Crustaceorum Catalogus Part 7, Pp. 1-173. SPB Academic Publishing, The Hague, The Netherlands.

Bate, C. S. 1856. On the British Diastylidae. - Annals and Magazine of Natural History (2) 17: 449-465.

$\rightarrow$ Bishop, J. D. D. 1981a. A revised definition of the genus Epileucon Jones (Crustacea, Cumacea), with descriptions of species from the deep Atlantic.Philosophical Transactions of the Royal Society of London (B) 291: 353-409.

$\rightarrow-$ 1981b. Two new leuconids (Peracarida, $\mathrm{Cu}-$ macea) of widespread occurrence in the deep Atlantic. - Crustaceana 40: 144-159.

- 1982. Three new species of the genus Leucon Krøyer, 1846 (Crustacea: Cumacea) from the continental slope off Surinam.-Zoological Journal of the Linnean Society $74: 345-357$.

Blake, C. H. 1929. New Crustacea from the Mount Desert region. - Biological Survey of the Mount Desert Region, Part 3, Pp. 1-34. Wistar Institute of Anatomy and Biology, Philadelphia, Pennsylvania.

Calman, W. T. 1905. The marine fauna of the west coast of Ireland, Part IV, Cumacea.-Scientific Investigations of the Fisheries Branch, Ireland, 1904, Appendix No. I: 3-52.

. 1907a. On new or rare Crustacea of the Order Cumacea from the collection of the Copenhagen $\mathrm{Mu}$ seum. - Transactions of the Zoological Society of London 18: 1-56.

- 1907b. Crustacea. II-Cumacea.-National Antarctic Expedition 1901-1904, Natural History 2: $1-6$.

. 1912. The Crustacea of the Order Cumacea in the collection of the United States National Museum.-Proceedings of the United States National Museum 41: 604-674.

Fage, L. 1951. Cumacés. - Faune de France 54: 1136.

Gamô, S. 1962. Leucon simanensis sp. nov. and $L$. varians sp. nov.-Zoological Magazine (Dobutsugaku Zasshi) 71: 256-261.

. 1964. On three new species of Cumacea from the southern Sea of Japan.-Crustaceana 7: 241253.
. 1967. Studies on the Cumacea (Crustacea, Malacostraca) of Japan. Part 1. - Publications of the Seto Marine Biological Laboratory 15: 133-163.

- 1987. Two new cumacean crustaceans, Paraleucon? ultraabyssalis sp. nov. and Leptostylis? spinescens sp. nov. from the Japan Trench. - Bulletin of the Biogeographical Society of Japan 42: 43-48.

- 1988. A new abyssal cumacean crustacean, Leucon stenorhynchus sp. nov. (Leuconidae) from the Japan Trench.-Bulletin of the Biogeographical Society of Japan 43: 25-28.

Given, R. R. 1961. The cumacean fauna of the Southern California continental shelf. No. 1, Family Leuconidae. - Bulletin of the Southern California Academy of Sciences 60: 129-146.

Hale, H., 1945. Australian Cumacea, No. 10. The Family Leuconidae. - Transactions of the Royal Society of South Australia 69: 86-95.

Hansen, H. 1920. Crustacea Malacostraca. IV.Danish Ingolf-Expedition 3: 1-86.

Hart, J. F. L. 1930. Some Cumacea of the Vancouver Island region. - Contributions to Canadian Biology and Fisheries 6: 25-40.

Jones, N. S. 1956. Cumacea from the west coast of Africa.-Atlantide Report 4: 183-212.

1963. The marine fauna of New Zealand: crustaceans of the Order Cumacea.-New Zealand Oceanographic Institute Memoir No. 23: 1-81.

- 1969. The systematics and distribution of Cumacea from depths exceeding 200 meters. -Galathea Report. Scientific Results of the Danish DeepSea Expedition Round the World 1950-52, 10: 100180.

Krøyer, H. 1841. Fire nye arter af Slaegten Cuma.Naturhistorisk Tidsskrift 3: 503-534.

. 1846. Carcinologiske bidrag.-Naturhistorisk Tidsskrift, Ser. 2, 2: 123-211.

Ledoyer, M. 1977. Cumacés (Crustacea) des Iles Kerguelen recueillis par le N. O. "La Japonaise" en 1972 et 1974 et par le M. S. "Marion-Dufresne" en 1974. Comité National Français des Recherches Antarctiques 42: 193-213.

- 1988. Cumacés (Crustacea) profonds de la région de l'ile de Mayotte, Canal de Mozambique, Océan Indien (Campagne Benthédi, 1977). - Mésogée (Bulletin du Muséum d'Histoire Naturelle de Marseille) 48: 131-172.

Liljeborg, W. 1855. Om hafs-crustaceer vid Kullaberg i Skåne.-Öfversigt af Kongliga VetenskapsAkademiens Förhandlingar 12: 117-138.

Lomakina, N. B. 1952. Novye interesnye v zoogeograficheskom otnoshenii nakhodki kumovykh rakov $\mathrm{v}$ dal'neyvostochnykh moryakh. [New zoogeographically interesting findings of Cumacea in Far Eastern Seas.]-Zoologicheskii Zhurnal 30: 244-248. [In Russian.]

- 1955. Kumovye raki (Cumacea) dal'nyevostochnykh moryakh. - Trudy Zoologicheskogo Instituta Akademia Nauka S.S.S.R. 18: 112-165. [In Russian.]

- 1967. Novye vedyi kumovye (Crustacea, $\mathrm{Cu}$ macea) iz sborov Sovetckoye Antarcticheskoi ekspedichii (1956-1958) u yogo-vostochnoye Australii i v severnoye chasti Indiiskogo okeana [New species of Cumacea collected by the Soviet Antarctic expedition at south-eastern Australia and in the north of the Indian Ocean]. - Trudy Zoologicheskogo Instituta, Leningrad 43: 99-108. 
Norman, A. M. 1867. On the Crustacea, Echinodermata, Polypora, Actinozoa and Hydrozoa. Report of the committee appointed for the purpose of exploring the coasts of the Hebrides by means of the dredge.-Report of the British Association for the Advancement of Science 36: 193-206.

. 1879. Crustacea Cumacea of the 'Lightning,' 'Porcupine,' and 'Valorous' Expeditions. - Annals and Magazine of Natural History (5)3: 54-73.

Ohlin, A. 1901. Arctic Crustacea collected during the Swedish Arctic Expeditions 1898 and 1899 under the direction of Professor A. G. Nathorst. I. Leptostraca, Isopoda, Cumacea.-Bihang till Kongliga Svenska Vetenskaps-Akademiens Handlingar 26: 154.

Sars, G. O. 1865. Om den aberrante krebsdygruppe Cumacea og den nordiske arter.-Förhandlingar i Videnskabs-Selskabet i Christiania 1864: 128-208.

- 1869. Undersögelser over Christianafyord dybvandsfauna. - Nyt Magazin for Naturvidenskaberne 11: 1-58.

- 1871. Nya arter af Cumacea samlade under K. Svenska Korvetten Josephines Expedition i Atlantiska Oceanen ar 1869 af F. A. Smitt och A. Ljungman. - Öfversigt af Kongliga Vetenskaps-Akademiens Förhandlingar 1: 71-81.

. 1878, 1879. Nye Bidrag til Kundskaben om Middelhavets Invertebratfauna. II. Middelhavets Cumaceer. - Archiv for Mathematik og Naturvidenskab 3: 461-512; 4: 1-144.

- 1882 . Oversigt af Norges Crustaceer med foreløbige bemaerkninger over de nye eller mindre bekjende Arter. 1.-Førhandlingar Videnskabs Selskabet Christiania 1882: 1-124.

1887. Report on the Cumacea collected by H.M.S. Challenger during the years 1873-1876. Report on the Scientific Results of the Voyage of the H.M.S. Challenger during the Years 1873-1876 under the Command of George S. Nares and Frank Tourle Thomson 19(55): 1-78.

- 1900. Cumacea.-An account of the Crustacea of Norway 3: 1-115. Bergen Museum, Bergen, Norway.

Smith, S. I. 1879. The stalk-eyed crustaceans of the Atlantic coast of North America, north of Cape Cod.-Transactions of the Connecticut Academy of Arts and Science 5: 27-136.
Stebbing, T. R. R. 1912. The Sympoda.-Annals of the South Africa Museum 10: 129-176.

Watling, L. 1977. Two new genera and a new subfamily of Bodotriidae (Crustacea: Cumacea) from eastern North America. - Proceedings of the Biological Society of Washington 89: 593-598.

1979. Marine flora and fauna of the northeastern United States. Crustacea: Cumacea. - National Oceanic and Atmospheric Administration Technical Report, National Marine Fisheries Circular 423: 1-23.

- , and O. Breedy. 1988. A new cumacean (Crustacea) genus from beaches of Golfo de Nicoya, Costa Rica.-Revista Biologia Tropica 36: 527-533.

Zimmer, C. 1902. Cumaceen.-Ergebnisse der Hamburger Magalhaensischen Sammelreise, 1892/93, 2: $1-18$.

. 1903. Die Cumaceen des Museums für Naturkunde in Berlin.-Zoologische Jahrbücher, Abtheilung für Systematik, Geographie und Biologie der Thiere 18: 664-694.

. 1907. California Crustacea of the Order $\mathrm{Cu}$ macea.-Proceedings of the United States National Museum 83: 423-439.

- 1908. Die Cumaceen der "Deutschen Tiefsee-Expedition". - Wissenschaftliche Ergebnisse der Deutschen Tiefsee-Expedition auf dem Dampfer "Valdivia" 1898-1899, 8: 158-196.

—. 1909. Die Cumaceen der Schwedischen Südpolarexpedition. - Wissenschaftliche Ergebnisse der Schwedischen Südpolar-Expedition 1901-1903, 6: $1-31$.

- 1926. Northern and Arctic invertebrates in the collection of the Swedish State Museum (Riksmuseum). - Kungliga Svenska Vetenskaps-Akademiens Handlingar 3: 1-88.

-1 1943. Cumaceen des Stillen Ozeans. - Archiv für Naturgeschichte 12: 130-174.

RECEIVED: 20 MARCH 1991.

ACCEPTED: 28 May 1991.

Address: Department of Oceanography, Darling Marine Center, University of Maine, Walpole, Maine 04573. 